\title{
Regulation of Respiratory and Fermentative Modes of Growth of Citrobacter freundii by Oxygen, Nitrate and Glucose
}

\author{
By C. W. KEEVIL, * J. S. HOUGH AND J. A. COLE \\ Department of Biochemistry, University of Birmingham, Birmingham B152TT
}

(Received 31 August 1978)

\begin{abstract}
The common brewery contaminant Citrobacter freundii has been used to investigate how oxygen, nitrate and glucose concentrations determine the growth rates, cell yields, the flux of metabolites and the rates of synthesis of tricarboxylic acid cycle enzymes and terminal electron transfer pathways. The growth rate was inhibited for 4 or $8 \mathrm{~h}$ when anaerobic batch cultures were either supplemented with nitrate or aerated, respectively. The subsequent exponential growth rates and yield coefficients were greater than in unsupplemented anaerobic cultures, but glucose was only partially oxidized to organic acids even in the most vigorously aerated cultures. The least active enzyme of the tricarboxylic acid cycle was succinate dehydrogenase, and although there were large differences in individual cytochrome concentrations and NADH oxidase activity between aerated and anaerobic cultures, only small differences in 2-oxoglutarate dehydrogenase activity were detected. Similar results were obtained with sulphate-limited continuous cultures, but in a glucoselimited continuous culture, succinate dehydrogenase activity was derepressed 12 -fold and the yield coefficient increased $7 \cdot 5$-fold during aerobic growth.

It is concluded that the major determinant of the potential tricarboxylic acid cycle activity is catabolite repression of succinate dehydrogenase synthesis rather than oxygen induction of 2-oxoglutarate dehydrogenase. Synthesis of 2-oxoglutarate dehydrogenase was derepressed, possibly by glutamate or by traces of oxygen in the gas used to sparge the culture during anaerobic growth.
\end{abstract}

\section{INTRODUCTION}

Inorganic electron acceptors such as oxygen and nitrate markedly alter the metabolism of micro-organisms which are able to grow anaerobically (Krebs, 1937; Pichinoty, 1963; Gray et al., 1966a; St John et al., 1974; Cavari et al., 1968; Yamamoto \& Ishimoto, 1975). Some of the many effects observed have been changes in cell yield, respiratory activity, enzyme activity, haemoprotein concentration and metabolic by-products. Although most studies have been concerned with the facultatively anaerobic bacteria Escherichia coli and Klebsiella aerogenes, many of the data are conflicting and little is known about how protein synthesis is controlled at the molecular level in response to the availability of terminal electron acceptors. Furthermore, few attempts have been made to correlate the in vitro activity of a particular enzyme with the quantity of its product that is formed in vivo.

Citrobacter freundii is taxonomically closely related to E. coli (De Graaf \& Stouthamer, 1971). It is a significant spoilage micro-organism in brewers' wort in which it must adapt to an anaerobic environment during the yeast fermentation. This transition is complicated by the presence of nitrate and high concentrations of glucose in brewers' wort (Weiner et al., 1975; Hough et al., 1971). Glucose (or catabolite) repression is a well-documented

* Present address: Tate \& Lyle Group Research and Development, P.O. Box 68, Reading RG6 2BX. 
phenomenon which is observed when glucose or another readily metabolized carbon compound decreases the intracellular concentration of $3^{\prime}: 5^{\prime}$-cyclic adenosine monophosphate and prevents the transcription of catabolite-sensitive genes (Magasanik, 1961; Tyler et al., 1967; Jacquet \& Kepes, 1969). For example, glucose represses the synthesis of tricarboxylic acid cycle enzymes in C. freundii (Keevil et al., 1977a) or in E. coli when this organism is grown in complex media (Gray et al., 1966 b). Furthermore, nitrate is a powerful oxidizing agent which can replace oxygen as the terminal electron acceptor for the respiratory chain of many bacteria, so its presence substantially influences the products that are formed during anaerobic growth (Krebs, 1937; Pichinoty, 1963). Nitrite, the product of nitrate reduction, can either be further reduced or accumulate as a substance toxic to yeast (Cole \& Wimpenny, 1968; Weiner et al., 1975). We have therefore investigated how glucose metabolism by Citrobacter freundii is modified when anaerobic cultures are supplied with the inorganic electron acceptors oxygen, nitrate and nitrite. Our aims were to determine the major regulatory mechanisms which promote a fermentative or respiratory mode of growth, and to correlate activities of individual enzymes (and therefore their rates of synthesis) with the rate at which they function during growth.

\section{METHODS}

Organism and media. Citrobacter freundii strain NCTC 9750 was maintained and grown in the minimal medium of De Graaf \& Stouthamer (1971) supplemented with glutamate, lysine, thiamin and methionine as described previously (Keevil et al., 1977b). Samples of each culture were routinely stained by Gram's method and observed microscopically. Single colony isolates were also stabbed into cyanide agar (Munson, 1974): Citrobacter species are resistant to KCN, but most other Enterobacteriaceae are sensitive. The identity of the pure culture from continuous cultures was confirmed with the 'API 10 Enterobacteriaceae System' of bacterial tests (D. A. Pitman, Weybridge, Surrey).

Continuous culture studies. The 51 fermentation vessel containing 2.8 to 3.01 medium was equipped with $\mathrm{pH}$ and temperature control (L. H. Engineering, Stoke Poges, Bucks.). The dilution rate for all experiments was $0.035 \mathrm{~h}^{-1}$, and the flow rate of medium into the fermenter was controlled with a peristaltic pump (Watson-Marlow, Falmouth). Anaerobic cultures were sparged at $50 \mathrm{ml} \mathrm{min}^{-1}$ with $\mathrm{N}_{2} / \mathrm{CO}_{2}(95: 5, \mathrm{v} / \mathrm{v})$ (British Oxygen Co., Wolverhampton): butyl rubber or silicone rubber tubing was used for all connections and no attempt was made to exclude $\mathrm{O}_{2}$ from the feed medium. Although pure $\mathrm{O}_{2}$ (British Oxygen Co.; $11 \mathrm{~min}^{-1}$ ) was used for experiments with sulphate-limited cultures to ensure that the dissolved $\mathrm{O}_{2}$ concentration remained above $200 \mu \mathrm{M}$, the same dissolved $\mathrm{O}_{2}$ concentration was subsequently achieved with 41 air $\min ^{-1}$. Air was therefore used in many of the experiments. The impeller speed was $600 \mathrm{rev}$. $\mathrm{min}^{-1}$. Steady-state growth was established by allowing $14 \mathrm{l}$ of medium to flow into the fermenter before a 21 sample was taken aseptically directly from the vessel. The purity and $A_{650}$ of the culture were checked with $20 \mathrm{ml}$ samples taken aseptically from a sampling port.

Batch culture experiments. Exponential phase cultures in $20 \mathrm{ml}$ of aerated nutrient broth were transferred into $500 \mathrm{ml}$ of supplemented minimal medium and incubated for $16 \mathrm{~h}$ at $37^{\circ} \mathrm{C}$ aerobically, or anaerobically with or without nitrate. These cultures provided $5 \%(\mathrm{v} / \mathrm{v})$ inocula for 101 of identical pre-warmed medium in a stirred fermenter equipped with $\mathrm{pH}$ and temperature control (L. H. Engineering). 'White spot' nitrogen was passed into the fermenter at $50 \mathrm{ml} \mathrm{min}{ }^{-1}$ during anaerobic growth. For aerobic growth, pure oxygen was supplied to the fermenter through the impeller at 1 or $51 \mathrm{~min}^{-1}$, and the culture was stirred at $600 \mathrm{rev} . \mathrm{min}^{-1}$. In initial experiments, flasks were aerated in an orbital shaker operating at 200 cycles min $^{-1}$ (model G-25, New Brunswick Scientific Co.). Neither the flasks nor the 101 fermenter were equipped with an oxygen electrode for these experiments.

Growth determinations. Cell densities (determined spectrophotometrically), the yield of bacterial dry weight (calculated from calibration curves) and the carbon content of washed cell suspensions were all determined as described by Keevil et al. (1977b).

Preparation of bacterial extracts. The 21 samples were cooled to $4^{\circ} \mathrm{C}$ and harvested by centrifuging at $15000 \mathrm{~g}$ for $10 \mathrm{~min}$. Cell-free extracts of soluble and membrane-bound proteins were prepared as described by Cole \& Rittenberg (1971) after bacteria had been broken with a Hughes' (1951) press: 0·1 M-potassium phosphate $\mathrm{pH} 7.0$ was used throughout.

Enzyme assays. Malate dehydrogenase (EC 1.1.1.37), aconitate hydratase (EC 4.2.1.3), pyruvate dehydrogenase (EC 1.2.4.1), succinate dehydrogenase (EC 1.3.99.1) and NADH oxidase activities were 
determined under optimal conditions of $\mathrm{pH}$ and substrate concentration, as described by Keevil et al. $(1977 a)$. Lactate dehydrogenase activity (EC 1.1.1.27) was determined by measuring the rate of oxidation of NADH by pyruvate: assay cuvettes contained $0.25 \mathrm{~mm}-\mathrm{NADH}, 1.5 \mathrm{~mm}$-sodium pyruvate and 30 to $50 \mu \mathrm{g}$ soluble protein extract in $1 \mathrm{ml} 50 \mathrm{~mm}$-potassium phosphate $\mathrm{pH} 6.5$. Higher concentrations of pyruvate were slightly inhibitory. Pyruvate was added last to initiate the reaction.

The three-component 2-oxoglutarate dehydrogenase complex (EC 1.2.4.2) was assayed using a modification of the method of Reed \& Mukherjee (1969). Concentrations of 2-oxoglutarate above $1.5 \mathrm{~mm}$ were inhibitory, especially with more than $6 \mathrm{~mm}-\mathrm{NAD}{ }^{+}$. Assay cuvettes therefore contained $1 \mathrm{~mm}-\mathrm{MgCl}_{2}$, $60 \mu$ M-coenzyme A, 0.2 mm-thiamin pyrophosphate, 3 mm-cysteine hydrochloride, $4 \mathrm{~mm}-\mathrm{NAD}^{+}, 1 \mathrm{~mm}$ potassium 2-oxoglutarate and 0.6 to $1.0 \mathrm{mg}$ soluble protein in $1 \mathrm{ml} 50 \mathrm{~mm}$-potassium phosphate $\mathrm{pH} 7 \cdot 5$. The reaction was started by adding 2-oxoglutarate.

Citrate synthase (EC 4.1.3.7), fumarate hydratase (EC 4.2.1.2) and isocitrate dehydrogenase (EC 1.1.1.42) were assayed as described by Weitzman (1969), Ochoa (1955) and Massey (1952), respectively. Alcohol dehydrogenase (EC 1.1.1.1) activity was determined as described by Kersters \& De Ley (1966) except that the ethanol concentration was $0.5 \mathrm{M}$.

Several of the enzymes of the tricarboxylic acid cycle from $C$. freundii were inhibited by high concentrations of substrates and coenzymes: the assay conditions specified above therefore differ significantly from those used in previous studies (Gray et al., 1966a).

Cytochrome spectra. Difference spectra of membrane-bound protein ( 3 to $9 \mathrm{mg} \mathrm{ml}^{-1}$ ) and soluble protein (10 to $20 \mathrm{mg} \mathrm{ml}^{-1}$ ) fractions diluted in $0 \cdot 1 \mathrm{M}$-potassium phosphate $\mathrm{pH} 7 \cdot 0$ were recorded at room temperature with a Unicam SP1800 or Perkin-Elmer 356 spectrophotometer at an absorbance range of 0 to $0.01,0.03$ or $0 \cdot 1$. Samples $(2.5 \mathrm{ml})$ were reduced by adding a few grains of sodium dithionite or oxidized by adding a small crystal of potassium ferricyanide, and their difference spectra between 490 and $650 \mathrm{~nm}$ were recorded. Samples which were to be oxidized with a crystal of $\mathrm{NaNO}_{2}$ were first reduced with a few grains of sodium dithionite. Carbon monoxide spectra were recorded as described by Cole \& Rittenberg (1971) with samples reduced with sodium dithionite. Difference spectra between 390 and $480 \mathrm{~nm}$ were recorded with samples treated repeatedly with carbon monoxide until no further increases in peak heights were observed. The millimolar absorption coefficients used to calculate the concentration of each cytochrome were 60 for the cytochrome $a_{1}-\mathrm{CO}$ chromophore (Smith, 1955), 80 for cytochrome $o-C O$ (Taber \& Morrison, 1964), 16 for cytochrome $a_{1}$ (Chance, 1961), 24.6 for cytochrome $b_{562}$ (Hager \& Itagaki, 1967), 17.5 for other $b$-type cytochromes, $8 \cdot 5$ for cytochrome $d$ (Jones \& Redfearn, 1966) and $24 \cdot 1$ for cytochrome $c_{552}$ (Fujita, 1966). Peak heights were measured as described by these authors.

Chemical estimations. Nitrite and nitrate were assayed colorimetrically by the methods of Radcliffe \& Nicholas (1968) and Szekely (1967), respectively. No colour developed when less than 20 nmol nitrate was added to assay tubes, but for larger samples up to $80 \mathrm{nmol}$ nitrate the colour intensity was directly proportional to the quantity of nitrate added: $20 \mathrm{nmol}$ potassium nitrate was therefore added to all assay tubes, including the reagent blank.

The dissolved oxygen concentration was measured with an oxygen electrode (Electrode Instruments, Richmond, Surrey).

Acetate and ethanol were determined by gas-liquid chromatography. Bacteria in samples of the culture were sedimented by centrifuging at $15000 \mathrm{~g}$ and $4^{\circ} \mathrm{C}$ for $10 \mathrm{~min}$, and $9 \mathrm{ml}$ of the supernatant was mixed with $1 \mathrm{ml} 3 \mathrm{M}$-polyphosphoric acid. After $20 \mathrm{~min}$ at 18 to $20^{\circ} \mathrm{C}$, precipitated protein was removed by centrifuging. Samples of the supernatant fluid $(0.5 \mu \mathrm{l})$ were injected on to a Tenax-GC column $(1.6 \mathrm{~m} \times 3 \mathrm{~mm}$ diam.; Enka, Holland) in a Pye 104 model 24 chromatograph equipped with a flame ionization detector. The column temperature was $125^{\circ} \mathrm{C}$ and the flow rate of $\mathrm{N}_{2}$ carrier gas was $30 \mathrm{ml} \mathrm{min}^{-1}$. Peak heights were proportional to the quantity of ethanol and acetate in the injected sample.

Carboxylic acids in the deproteinized culture fluid were methylated with $\mathbf{B F}_{3}-$ methanol complex prior to quantification by gas-liquid chromatography (Harmon \& Doelle, 1969). Samples (5 $\mu$ ) of chloroform extracts of the esters were injected on to a polyethylene glycol succinate column (glass, $1.6 \mathrm{~m} \times 3 \mathrm{~mm}$; Phase Separations, Rock Ferry, Cheshire). The flow rate of $\mathrm{N}_{2}$ carrier gas was $20 \mathrm{ml} \mathrm{min}{ }^{-1}$. A typical programme consisted of holding the initial column temperature at $60^{\circ} \mathrm{C}$ for $2 \mathrm{~min}$ to allow the detection of methyl formate, then increasing the temperature by $10^{\circ} \mathrm{C} \mathrm{min}-1$ to detect pyruvate, lactate, fumarate and succinate esters, and finally holding the temperature at $165^{\circ} \mathrm{C}$ for $15 \mathrm{~min}$ to detect methyl esters of 2oxoglutarate, isocitrate and citrate. Standard solutions of salts of each acid were methylated in parallel with test samples, and linear calibration curves were constructed to relate peak heights to the quantity of methyl ester injected.

Carbon dioxide evolved during growth in the 101 batch fermenter was estimated by passing effluent gases through two $250 \mathrm{ml}$ Dreschel bottles containing $100 \mathrm{ml} 2 \mathrm{M}-\mathrm{KOH}$. Finely sintered glass diffusers were incorporated into these $\mathrm{CO}_{2}$ traps to provide efficient sparging. The concentration of bicarbonate ion in 
$5 \mathrm{ml}$ samples of the $\mathrm{KOH}$ was determined at intervals during growth by pipetting duplicate 0.1 to $2.0 \mathrm{ml}$ samples into Warburg manometers and adding $1 \mathrm{ml} 5 \mathrm{M}-\mathrm{H}_{2} \mathrm{SO}_{4}$ to the side arm. When the manometers had equilibrated at $30^{\circ} \mathrm{C}$, the $\mathrm{H}_{2} \mathrm{SO}_{4}$ was tipped into the $\mathrm{KOH}$ sample and the volume of $\mathrm{CO}_{2}$ evolved was determined. Little $\mathrm{CO}_{2}$ was evolved when the $\mathrm{KOH}$ samples were replaced by $5 \mathrm{ml}$ samples of the culture supernatant.

Ammonia was determined as described by Muramatsu (1967) with $\mathrm{NH}_{4} \mathrm{Cl}$ as a standard, and protein concentrations were determined by the Folin method with bovine serum albumin as the standard (Lowry et al., 1951).

Glucose could not be assayed by the glucose oxidase method because of interference by unidentified compounds in some, but not all, cultures: the method of Dubowski.(1962) was therefore used. The molar growth yield $\left(Y_{\text {glucose }}\right)$ was calculated by dividing the increase in the concentration of bacterial dry weight by the decrease in glucose concentration. Note that differences in $Y_{\text {glucose }}$ between cultures are not necessarily paralleled by differences in the percentage of glucose-carbon which was calculated to be incorporated into cell carbon (Tables 1 and 5). Apart from experimental errors, which were of the order of $1 \%$ for each determination, these data are subject to different types of systematic error. $Y_{\text {glucose }}$ values are calculated from dry weight estimations, which in turn are derived from calibration curves relating the culture turbidity to the concentration of bacterial dry weight. Although calibration curves constructed for aerobic and anaerobic batch cultures were superimposable, the assumption that a similar relationship would apply for each of the culture conditions used was not verified. In contrast, the percentage of glucose-carbon converted into cellular carbon would be overestimated for any continuous culture in which a significant fraction of cell carbon was derived from $\mathrm{CO}_{2}$ in the gas supplied to the culture.

Reproducibility of the data. Each column of data in the Tables is for a single batch culture or continuous culture steady state. The reproducibility of data from independent cultures has been documented by Keevil et al. $(1977 a, b)$. Duplicates of enzyme assays other than NADH oxidase agreed to within $1 \%$; replicate NADH oxidase activities and cytochrome determinations agreed to within $5 \%$. All chemical estimations except nitrate and protein assays were duplicated, and duplicates agreed to within $1 \%$. Nitrate and protein assays were triplicated and the range of measured values was less than $5 \%$ of the mean for protein and $10 \%$ of the mean for nitrate.

\section{RESULTS}

\section{Adaptation from aerobic to anaerobic growth in batch culture}

Growth rates. The complexity of the transition from anaerobic to aerobic growth became apparent from preliminary experiments in which cultures of Citrobacter freundii which had been grown anaerobically for $16 \mathrm{~h}$ in supplemented minimal medium were transferred into similar medium and aerated. For comparison, further cultures were incubated anaerobically with or without nitrate. Initially, the aerated culture grew with the lowest specific growth rate of $0.057 \mathrm{~h}^{-1}$, but after $8 \mathrm{~h}$ this increased to $0.57 \mathrm{~h}^{-1}$ (Fig. 1 $a$ ). The initial specific growth rate of the anaerobic culture supplemented with nitrate was $0 \cdot 11 \mathrm{~h}^{-1}$, but this increased after $4 \mathrm{~h}$ to $0.21 \mathrm{~h}^{-1}$. Thus, although the ultimate growth rate increased with increasing redox potential of the culture, there were corresponding decreases in the initial growth rates and increases in the lag before the optimal growth rates were obtained. These lag phases were possibly due to inactivation of fermentative metabolic processes by oxygen or nitrate before respiratory metabolism could commence.

In subsequent experiments, when pure $\mathrm{O}_{2}$ was passed into the 101 fermenter at a rate of $11 \mathrm{~min}^{-1}$, exponential growth commenced immediately at a rate of $0.26 \mathrm{~h}^{-1}$ (Fig. $1 \mathrm{~b}$ ). After $2 \mathrm{~h}$, the aeration rate was increased to $51 \mathrm{O}_{2} \mathrm{~min}^{-1}$ and the specific growth rate increased to $0.495 \mathrm{~h}^{-1}$. The specific rates of exponential growth of cultures grown anaerobically with or without nitrate were 0.69 and $0.495 \mathrm{~h}^{-1}$, respectively. Although the anaerobic growth rates were faster in the stirred fermenter than in unstirred flasks, the aerobic growth rate was slower even with the highest rate of aeration. The extended period of exponential growth in the aerated cultures suggests that growth was not oxygen-limited.

Analysis of fermentation products and the establishment of carbon balances. Substantial concentrations of acetate, ethanol, formate, pyruvate, lactate and succinate accumulated during anaerobic growth without nitrate: these products are typical of a mixed acid fermentation. However, large quantities of partial oxidation products of glucose metabolism 

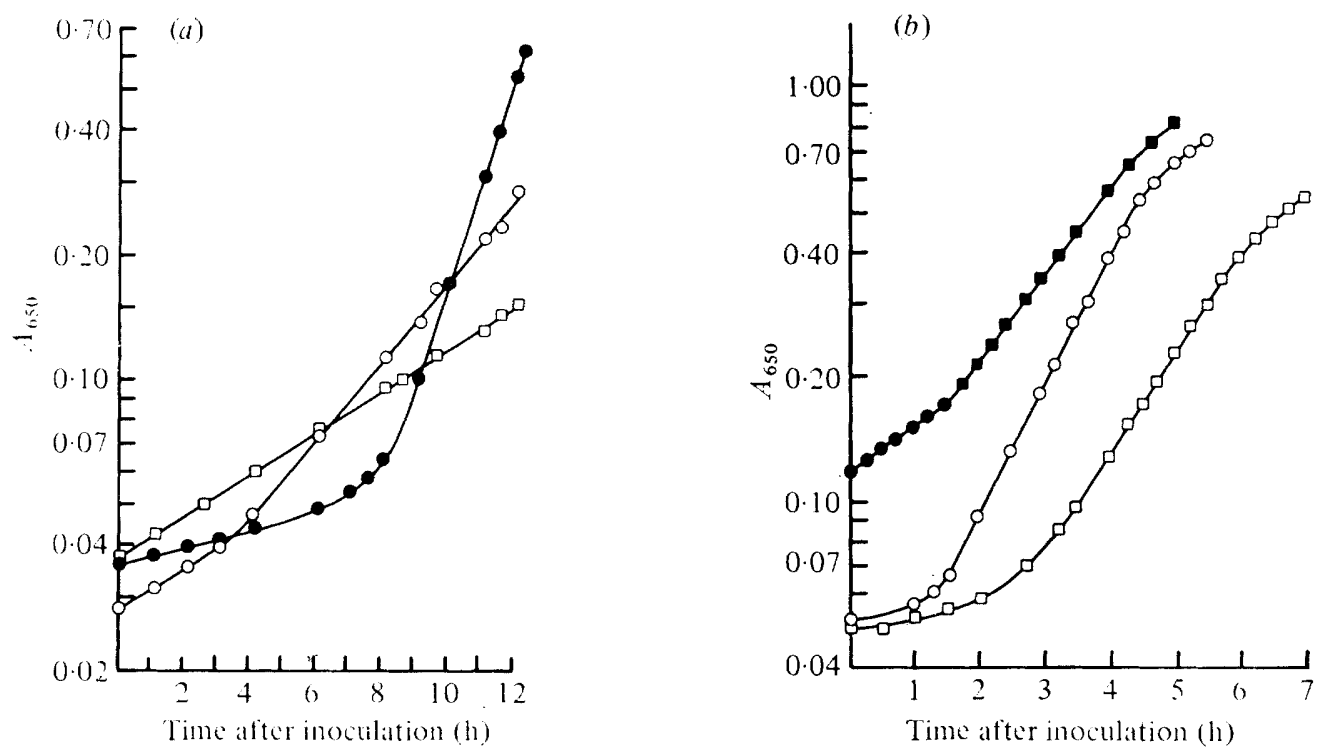

Fig. 1. Effect of inorganic electron acceptors on the anaerobic growth rate of $C$. freundii. In $(a)$, bacteria were first grown anaerobically in $100 \mathrm{ml}$ of supplemented minimal medium, $\mathrm{pH} 6.5$, at $37^{\circ} \mathrm{C}$ for $16 \mathrm{~h}$. The exponentially growing culture provided a $1 \%(\mathrm{v} / \mathrm{v})$ inoculum for $100 \mathrm{ml}$ of similar medium, either in $100 \mathrm{ml}$ conical flasks for anaerobic growth $(\square)$ or anaerobic growth with $50 \mathrm{~mm}-\mathrm{KNO}_{3}(\bigcirc)$, or in sterile $250 \mathrm{ml}$ conical flasks for aerobic growth in a shaking waterbath $(\odot)$. In $(b), 20 \mathrm{ml}$ inocula in aerated nutrient broth were transferred to $500 \mathrm{ml}$ of supplemented minimal medium, incubated for $16 \mathrm{~h}$ at $37^{\circ} \mathrm{C}$ and then transferred into 101 of similar medium in the stirred fermenter: $\square$, anaerobic culture without nitrate; $O$, anaerobic culture with 80 mm-nitrate; $\bullet$, aerated culture sparged with $11 \mathrm{O}_{2} \mathrm{~min}^{-1} ; \mathbf{Q}$, aerated culture sparged with $51 \mathrm{O}_{2} \mathrm{~min}^{-1}$. In both (a) and $(b)$, the initial glucose concentration was $20 \mathrm{~mm}$.

were also formed during aerobic growth or during anaerobic growth with nitrate, and rates of glucose utilization and soluble product formation increased exponentially during exponential growth. Standard solutions of acetoin, 2,3-butanediol, propionate and butyrate were readily resolved by the gas-liquid chromatographic procedures used, but none of these compounds was detected in the spent growth medium. No methylglyoxal was detected in any culture: because only a small fraction of the metabolized glucose remained unidentified, no further attempts were made to identify minor products.

The percentage of glucose-carbon recovered at the end of exponential growth as biomass or in soluble fermentation products averaged $97 \%$ for cultures grown anaerobically and $90 \%$ for cultures grown aerobically (Table 1). In the latter case, no attempt was made to measure the quantity of $\mathrm{CO}_{2}$ evolved: this was probably the reason for the incomplete carbon recovery. Glucose was still detectable in the culture at the end of exponential growth: it was not, therefore, the growth-limiting factor.

The percentage of glucose-carbon incorporated into biomass increased when inorganic electron acceptors were present: for anaerobic cultures supplemented with nitrate, this amounted to $34 \%$, or approximately twice that of cultures grown without nitrate. Rapid sparging rates with pure oxygen were required to obtain an even greater conversion of glucose-carbon into biomass in aerated cultures: at a flow rate of 11 pure $\mathrm{O}_{2} \mathrm{~min}^{-1}$, biomass production accounted for only $30 \%$ of the culture carbon, but this increased to $40 \%$ when the oxygen flow rate was $51 \mathrm{~min}^{-1}$. The evolution of $\mathrm{CO}_{2}$ accounted for only a small percentage of the carbon in cultures sparged with ' white spot' $\mathrm{N}_{2}$, but this low figure might reflect the demand by bacteria for $\mathrm{CO}_{2}$ for carboxylation reactions. More $\mathrm{CO}_{2}$ was evolved during anaerobic growth with nitrate, however, and the percentage of carbon accumulating 


\section{Table 1. Carbon balances for $C$. freundii during growth in a batch fermenter}

The percentage of glucose-carbon metabolized to volatile products was calculated from the difference between the initial carbon concentration of the growth medium and the sum of the cell carbon and supernatant carbon concentrations. The initial glucose concentration was $20 \mathrm{~mm}$.

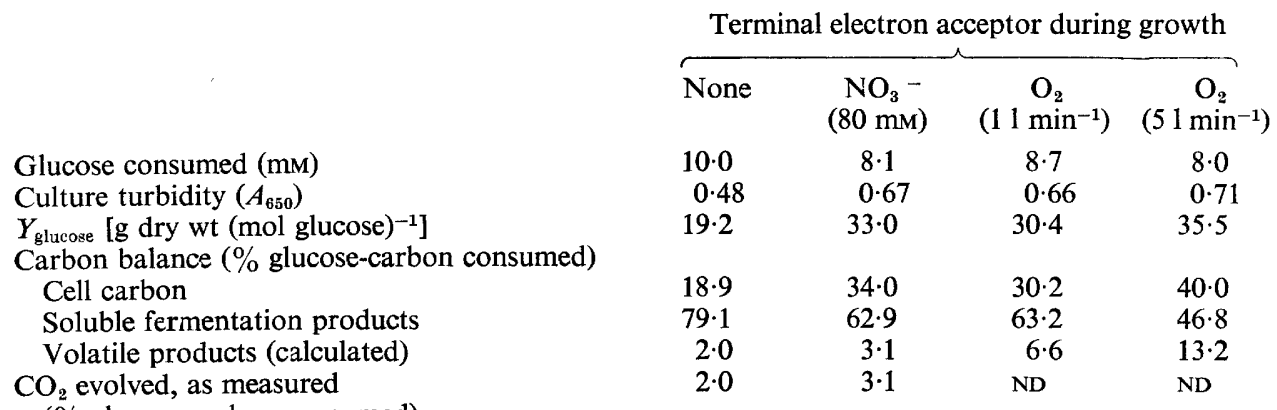

ND, Not determined.

Table 2. Analysis of soluble fermentation products in culture supernatants of $C$. freundii grown in $10 \mathrm{l}$ batch cultures with or without inorganic electron acceptors

Concentrations are expressed as the percentage of glucose-carbon metabolized.

Terminal electron acceptor during growth

$\begin{array}{lrrrr}\begin{array}{l}\text { Fermentation } \\ \text { product }\end{array} & \text { None } & \begin{array}{c}\mathrm{NO}_{3}- \\ (80 \mathrm{mM})\end{array} & \begin{array}{c}\mathrm{O}_{2} \\ \left(11 \mathrm{~min}^{-1}\right)\end{array} & \begin{array}{c}\mathrm{O}_{2} \\ \left(51 \mathrm{~min}^{-1}\right)\end{array} \\ \text { Formate } & 6.0 & 3.0 & 0.1 & 0.1 \\ \text { Acetate } & 17.8 & 32.3 & 28.0 & 17.7 \\ \text { Ethanol } & 16.8 & 1.7 & 0.7 & 0.1 \\ \text { Lactate } & 10.0 & 3.0 & 1.5 & 1.0 \\ \text { Pyruvate } & 12.5 & 10.0 & 18.5 & 16.7 \\ \text { Fumarate } & 0.1 & 0.1 & 0.1 & 2.4 \\ \text { Succinate } & 13.0 & 10.0 & 14.5 & 1.0 \\ \text { Malate } & 0.5 & 0.5 & 0.5 & 8.0 \\ \text { Isocitrate } & 0.8 & 0.1 & 2.0 & 5.0 \\ \text { Citrate } & 0.4 & 0.9 & 1.1 & 1.6 \\ \text { Unidentified } & 1.8 & 1.9 & 3.5 & 6.6\end{array}$

as formate, one of the precursors of $\mathrm{CO}_{2}$ in anaerobic metabolism, was lower in nitratesupplemented cultures than in unsupplemented cultures (Table 2). No formate was detected in aerated cultures. During anaerobic growth without nitrate, ethanol and acetate accounted for the largest percentage of the supernatant carbon, together with pyruvate, lactate and succinate. In contrast, cultures supplemented with nitrate produced less pyruvate, succinate and, especially, lactate: although far less ethanol accumulated, there was a corresponding increase in the concentration of acetate. In addition, similar quantities of ethanol and acetate were found in poorly aerated cultures and in the nitrate-supplemented cultures, but in the former $33 \%$ of the carbon accumulated as pyruvate and succinate, and only $1.5 \%$ as lactate. No ethanol and far less acetate and succinate were formed when the aeration rate was increased, but isocitrate, fumarate and malate now accounted for a significant percentage of the metabolized carbon.

Enzyme activities and cytochrome concentrations after growth in batch culture. Activities of every enzyme assayed were readily detectable in cell-free extracts of bacteria which had been harvested at the end of exponential growth under all four growth conditions (Table 3 ). The least active enzyme of the tricarboxylic acid cycle was succinate dehydrogenase, even though the assay used would have detected the sum of the succinate dehydrogenase and fumarate reductase activities: the latter enzyme was almost certainly responsible for the 
Table 3. Enzyme activities in cell membrane and soluble protein fractions of $C$. freundii grown in $10 \mathrm{l}$ batch cultures with or without inorganic electron acceptors

Units of enzyme activity are nmol $\mathrm{NAD}^{+}$reduced or NADH oxidized $\min ^{-1}$ (mg protein $)^{-1}$ or nmol substrate converted $\min ^{-1}(\mathrm{mg} \text { protein })^{-1}$.

\begin{tabular}{lccrr} 
& \multicolumn{3}{c}{ Terminal electron acceptor during growth } \\
\cline { 2 - 5 } \multicolumn{1}{c}{ Enzyme } & None & $\begin{array}{c}\mathrm{NO}_{3}- \\
(80 \mathrm{mM})\end{array}$ & $\begin{array}{c}\mathrm{O}_{2} \\
\left(11 \mathrm{~min}^{-1}\right)\end{array}$ & $\begin{array}{c}\mathrm{O}_{2} \\
\left(51 \mathrm{~min}^{-1}\right)\end{array}$ \\
Alcohol dehydrogenase & 20 & 14 & 8 & 2 \\
Lactate dehydrogenase & 830 & 100 & 760 & 350 \\
Pyruvate dehydrogenase & 110 & 48 & 260 & 285 \\
Citrate synthase & 38 & $\mathrm{ND}$ & 206 & $\mathrm{ND}$ \\
Aconitate hydratase & 42 & $\mathrm{ND}$ & 45 & $\mathrm{ND}$ \\
Isocitrate dehydrogenase & 310 & $\mathrm{ND}$ & 270 & $\mathrm{ND}$ \\
2-Oxoglutarate dehydrogenase & 34 & 34 & 48 & 43 \\
Succinate dehydrogenase & 15 & 21 & 15 & 6 \\
Fumarate hydratase & 450 & $\mathrm{ND}$ & 480 & $\mathrm{ND}$ \\
Malate dehydrogenase & 650 & 3300 & 4600 & 3500 \\
NADH oxidase & 75 & 120 & 300 & 330
\end{tabular}

ND, Not determined.

higher apparent activity of anaerobic cultures and for the high rate of succinate synthesis. 2-Oxoglutarate dehydrogenase was almost as active in anaerobic cultures as in aerobic cultures, but NADH oxidase activity almost doubled when anaerobic cultures were supplemented with nitrate, and increased fourfold in aerated cultures.

No significant concentrations of cytochromes were detected in soluble cell-free extracts. Cytochromes with absorption maxima at 557,562 and $590 \mathrm{~nm}$ were found in the particulate fraction of bacteria which had been grown anaerobically without nitrate: they were tentatively designated cytochromes $b_{557}, b_{562}$ and $a_{1}$, respectively (Table 4). Absorption maxima at 414 and $440 \mathrm{~nm}$ were resolved by carbon monoxide difference spectroscopy: these correspond to cytochromes $o$ and $a_{1}$, respectively (Lemberg \& Barrett, 1973). Far higher concentrations of a $b$-type cytochrome with an absorption maximum at $559 \mathrm{~nm}$ were detected after anaerobic growth with nitrate, and this prevented the detection of cytochromes $b_{557}$ and $b_{562}$ : these bacteria also contained a high concentration of cytochrome $d$. On the basis of published absorption coefficients one can calculate that cytochrome $o$ was the dominant cytochrome oxidase under all three growth conditions (Table 4). However, the absorption maximum of the cytochrome 0 - $\mathrm{CO}$ chromophore varied between 414 and $418 \mathrm{~nm}$. The concentrations of cytochromes $o$ and $b_{562}$ in bacteria grown aerobically were double those in bacteria grown anaerobically.

Nitrogen balance during anaerobic growth with nitrate. Samples of cultures growing anaerobically with nitrate were withdrawn during growth, and the deproteinized supernatant fluids were assayed for nitrate, nitrite and ammonium ions (Fig. 2). When $A_{650}$ had reached $0 \cdot 72$, the concentration of nitrate had decreased by $32 \mathrm{~mm}$ but only $23 \mathrm{~mm}$-nitrite had accumulated. Thus, contrary to previous reports that $C$. freundii is unable to reduce nitrite (Payne, 1973), 9 mm-nitrate had been reduced further than nitrite: because no gaseous denitrification products were detected, it is assumed that this nitrite is reduced to $\mathrm{NH}_{4}{ }^{+}$. The concentrations of individual amino acids in the culture were extremely low, the sum corresponding to less than $1 \%$ of the carbon metabolized. From the overall decrease in the concentration of $\mathrm{NH}_{4}{ }^{+}$of $14 \mathrm{mM}$, it can be calculated that $23 \mathrm{~mm}-\mathrm{N}$ had been assimilated.

\section{Aerobic and anaerobic metabolism by glucose- or sulphate-limited continuous cultures}

Data from the batch culture experiments indicated that respiratory metabolism by aerated cultures was either repressed by excess glucose or was limited by the supply of 


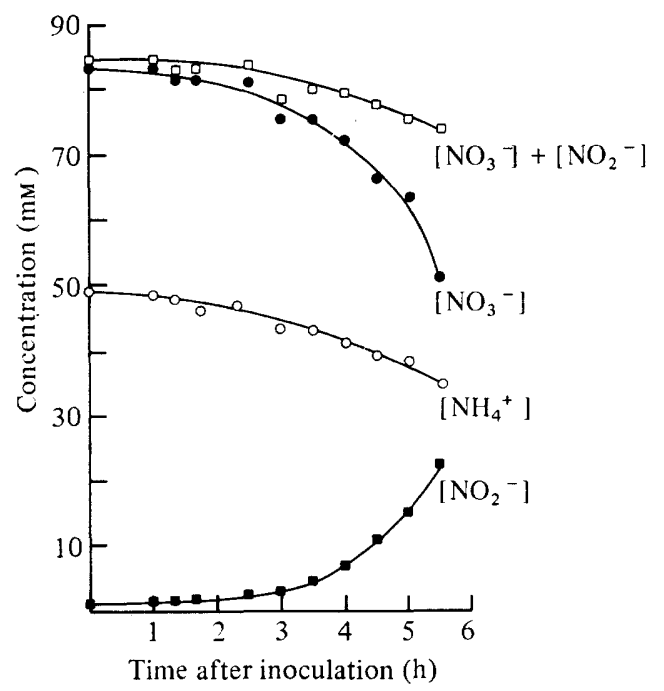

Fig. 2. Nitrogen balance of $C$. freundii during anaerobic growth with nitrate.

Table 4. Concentration of cytochromes in cell membrane fractions of $C$. freundii grown in 10 l batch cultures with or without inorganic electron acceptors

Concentration units are pmol (mg protein) ${ }^{-1}$.

Terminal electron acceptor during growth

Cytochrome

$o$
$a_{1}$
$b_{559}$
$b_{562}$
$d$
$b_{557}$

Type of spectrum

Reduced plus $\mathrm{CO}$ against reduced

Reduced against ferricyanide oxidized

Reduced against ferricyanide oxidized

Reduced against ferricyanide oxidized

Reduced against nitrite oxidized

Reduced against nitrite oxidized

$\begin{array}{rcc}\text { None } & \begin{array}{c}\mathrm{NO}_{3}- \\ (80 \mathrm{mM})\end{array} & \begin{array}{c}\mathrm{O}_{2} \\ \left(51 \mathrm{~min}^{-1}\right)\end{array} \\ 70 & 275 & 145 \\ 31 & 18 & 25 \\ \mathrm{ND} & 520 & \text { ND } \\ 80 & \mathrm{ND} & 160 \\ \mathrm{ND} & 140 & \text { ND } \\ 40 & \text { ND } & \text { D }\end{array}$

ND, Not detected; $D$, detected, but insufficiently resolved to quantify.

oxygen. Citrobacter freundii was therefore subsequently grown in vigorously stirred continuous culture with either $60 \mathrm{~mm}$-glucose and a growth-limiting supply of sulphate, or with $30 \mathrm{~mm}$-glucose and excess sulphate. In the former case, the cell density doubled when the concentration of sulphate in the feed medium was doubled, and excess glucose was readily detected in the spent culture medium. Conversely, no glucose was detected in the spent medium from the glucose-limited steady states, and the cell concentration decreased by $50 \%$ when the glucose concentration in the feed medium was reduced to $15 \mathrm{~mm}$. Aerobic and anaerobic steady states were established, as well as anaerobic, sulphate-limited steady states with media supplemented with $20 \mathrm{~mm}-\mathrm{KNO}_{3}$ or $20 \mathrm{~mm}-\mathrm{NaNO}_{2}$.

Fermentation products and carbon balances during continuous growth. Almost all of the 60 mM-glucose supplied to the sulphate-limited cultures was metabolized (Table 5). Yields from glucose were only slightly higher in the aerated culture or in anaerobic cultures supplemented with nitrate or nitrite than in the unsupplemented anaerobic cultures, but were far higher in the aerated glucose-limited cultures. Conversely, only low concentrations of soluble organic acids accumulated in the aerated, carbon-limited cultures, and $36 \%$ of the input carbon was evolved as volatile products (presumably as $\mathrm{CO}_{2}$ ).

The major fermentation products in both types of unsupplemented anaerobic culture 
Table 5. Carbon balances for C. freundii during growth in continuous culture

When sulphate was the limiting nutrient, the glucose concentration was $60 \mathrm{~mm}$; the glucose concentration for carbon-limited cultures was $30 \mathrm{~mm}$.

\begin{tabular}{|c|c|c|c|c|c|c|}
\hline & None & $\begin{array}{l}\mathrm{NO}_{2}^{-} \\
(20 \mathrm{mM})\end{array}$ & $\begin{array}{c}\mathrm{NO}_{3}^{-} \\
(20 \mathrm{mM})\end{array}$ & $\begin{array}{c}\mathrm{O}_{2} \\
\left(11 \mathrm{~min}^{-1}\right)\end{array}$ & None & $\begin{array}{c}\mathrm{O}_{2} \\
\left.\text { (41 air } \min ^{-1}\right)\end{array}$ \\
\hline $\begin{array}{c}\text { Growth-limiting } \\
\text { nutrient } \quad \ldots\end{array}$ & Sulphate & Sulphate & Sulphate & Sulphate & Glucose & Glucose \\
\hline Glucose consumed (mM) & $57 \cdot 8$ & $58 \cdot 7$ & $57 \cdot 4$ & 54.9 & 30 & 30 \\
\hline Culture turbidity $\left(A_{650}\right)$ & 0.98 & $1 \cdot 20$ & $1 \cdot 15$ & $1 \cdot 10$ & 0.83 & $4 \cdot 5$ \\
\hline $\begin{array}{l}Y_{\text {glucose }}[\mathrm{g} \text { dry wt }(\mathrm{mol} \\
\text { glucose })^{-1} \text { ] }\end{array}$ & $6 \cdot 8$ & $8 \cdot 1$ & $8 \cdot 0$ & $8 \cdot 0$ & $11 \cdot 1$ & $60 \cdot 0$ \\
\hline \multicolumn{7}{|c|}{$\begin{array}{l}\text { Carbon balance } \\
\text { (\% glucose-carbon consumed) }\end{array}$} \\
\hline Cell carbon & $8 \cdot 0$ & $12 \cdot 0$ & $12 \cdot 2$ & $14 \cdot 0$ & 11.0 & $58 \cdot 2$ \\
\hline $\begin{array}{l}\text { Soluble fermentation } \\
\text { products }\end{array}$ & $71 \cdot 5$ & $70 \cdot 0$ & $68 \cdot 3$ & $56 \cdot 1$ & $68 \cdot 0$ & $5 \cdot \overline{4}$ \\
\hline $\begin{array}{l}\text { Volatile products } \\
\text { (calculated)* }\end{array}$ & $20 \cdot 5$ & $18 \cdot 0$ & $19 \cdot 5$ & $29 \cdot 9$ & $21 \cdot 0$ & $36 \cdot 4$ \\
\hline
\end{tabular}

Table 6. Analysis of soluble fermentation products of $C$. freundii after growth in continuous culture

Concentrations are expressed as the percentage of glucose-carbon metabolized.

Terminal electron acceptor during growth

\begin{tabular}{|c|c|c|c|c|c|c|}
\hline & & & & & & \\
\hline & None & $\begin{array}{c}\mathrm{NO}_{2}^{-} \\
(20 \mathrm{mM})\end{array}$ & $\begin{array}{c}\mathrm{NO}_{3}^{-} \\
(20 \mathrm{mM})\end{array}$ & $\begin{array}{c}\mathrm{O}_{2} \\
\left(11 \mathrm{~min}^{-1}\right)\end{array}$ & None & $\underset{\left(41 \text { air min }^{-1}\right)}{\mathrm{O}_{2}}$ \\
\hline $\begin{array}{l}\text { Growth-limiting } \\
\text { nutrient } \ldots \\
\text { Fermentation product }\end{array}$ & Sulphate & Sulphate & Sulphate & Sulphate & Glucose & Glucose \\
\hline Formate & 0.4 & 0.5 & 0.8 & 0.4 & $1 \cdot 0$ & $<0.1$ \\
\hline Acetate & $21 \cdot 0$ & $29 \cdot 1$ & $28 \cdot 8$ & $17 \cdot 4$ & $25 \cdot 0$ & $0 \cdot 1$ \\
\hline Ethanol & $30 \cdot 2$ & 14.9 & $10 \cdot 7$ & 0.5 & $18 \cdot 7$ & $0 \cdot 1$ \\
\hline Lactate & $2 \cdot 1$ & $9 \cdot 4$ & $10 \cdot 9$ & $3 \cdot 2$ & $1 \cdot 0$ & $<0.1$ \\
\hline Pyruvate & $0 \cdot 3$ & 0.1 & $0 \cdot 1$ & $22 \cdot 0$ & $0 \cdot 1$ & $<0.1$ \\
\hline Succinate & $7 \cdot 7$ & $12 \cdot 4$ & $10 \cdot 0$ & $0 \cdot 3$ & $13 \cdot 4$ & $<0.1$ \\
\hline Malate & $0 \cdot 1$ & $2 \cdot 6$ & $2 \cdot 0$ & $11 \cdot 0$ & $8 \cdot 5$ & $<0.1$ \\
\hline Isocitrate & $0 \cdot 1$ & 0.3 & $0 \cdot 1$ & $4 \cdot 0$ & $0 \cdot 1$ & $<0.1$ \\
\hline Citrate & $0 \cdot 1$ & 0.5 & 0.5 & $3 \cdot 7$ & $0 \cdot 1$ & $<0 \cdot 1$ \\
\hline Unidentified & $9 \cdot 8$ & $2 \cdot 3$ & $6 \cdot 5$ & $3 \cdot 6$ & 8.9 & $5 \cdot 2$ \\
\hline
\end{tabular}

were acetate, ethanol and succinate, and, as in the previous batch cultures, the concentration of ethanol decreased and acetate increased when nitrate or nitrite was supplied. Neither nitrate nor nitrite was detected in the spent culture fluid. Only traces of identifiable fermentation products were detected in the aerated, carbon-limited culture. High concentrations of acetate, malate and, especially, pyruvate accumulated in the aerated, sulphatelimited culture, essentially similar to the data for the most vigorously aerated batch culture (compare Tables 2 and 6).

Enzyme activities and cytochrome concentrations. All of the enzymes assayed were sufficiently active to be detected in bacteria after growth in glucose- or sulphate-limited continuous culture, and, as in the preceding batch culture experiments, the least active enzyme of the tricarboxylic acid cycle was succinate dehydrogenase (Table 7). Nevertheless, this enzyme was 12 times more active in an aerated, carbon-limited culture than in the sulphate-limited culture, and 6 times more active than in bacteria grown in the most aerated 
Table 7. Enzyme activities in cell-free extracts of $C$. freundii after growth in continuous culture

Units of enzyme activity are nmol $\mathrm{NAD}^{+}$reduced or $\mathrm{NADH}$ oxidized $\mathrm{min}^{-1}(\mathrm{mg} \text { protein })^{-1}$ or nmol substrate converted $\min ^{-1}\left(\mathrm{mg}\right.$ protein) ${ }^{-1}$.

Terminal electron acceptor during growth

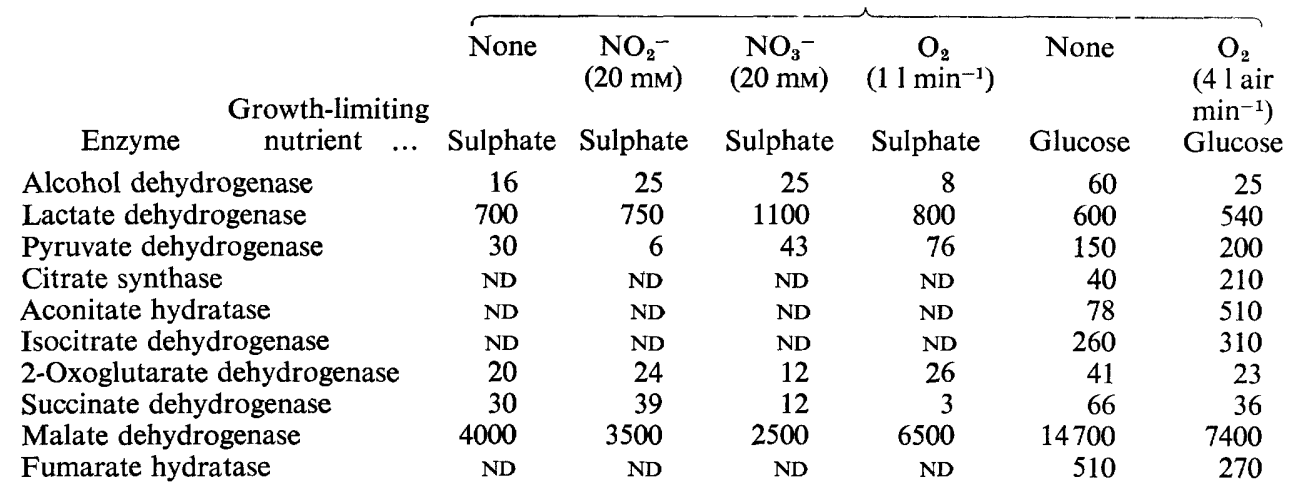

ND, Not determined.

Table 8. Cytochrome concentrations in cell membrane and soluble protein fractions of C. freundii after growth in continuous culture

Concentration units are pmol (mg protein) ${ }^{-1}$.

Terminal electron acceptor during growth

Cytochrome Type of spectrum

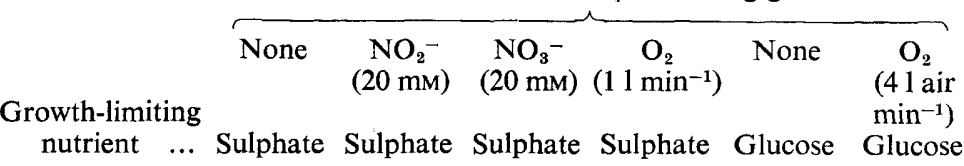

Membrane fraction

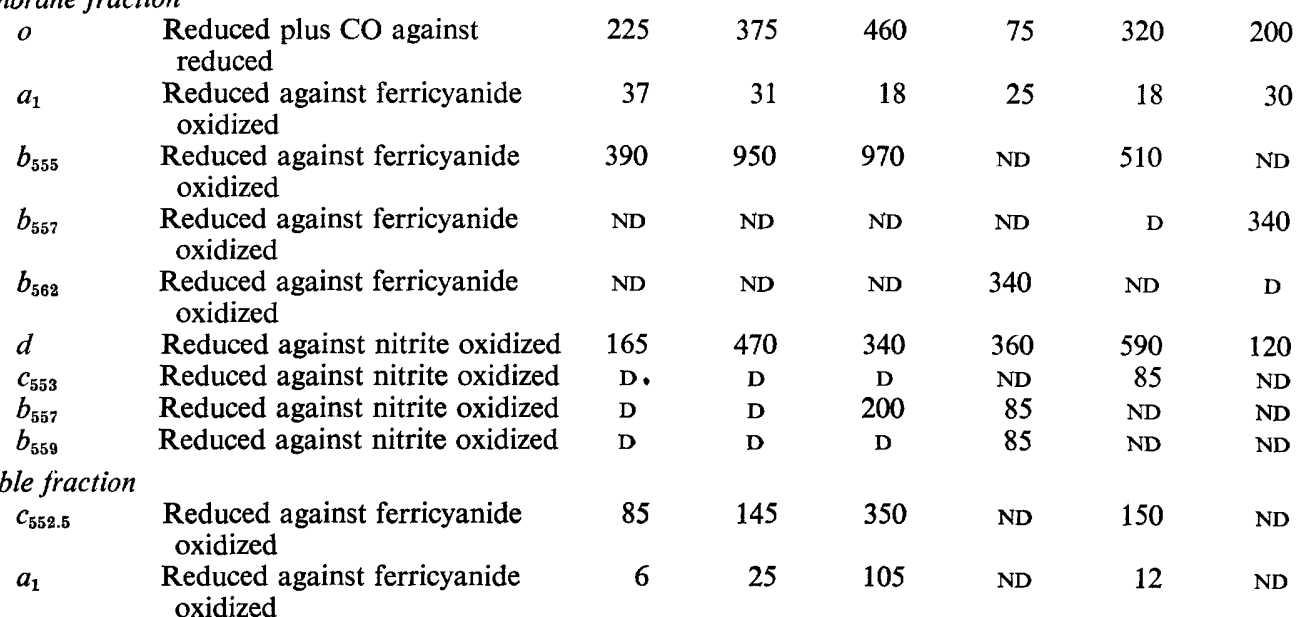

ND, Not detected; D, detected, but insufficiently resolved to quantify. 
batch culture. Once again, substantial 2-oxoglutarate dehydrogenase activity was detected in bacteria which had been grown anaerobically, and there were no correlations between the activities of lactate, alcohol and succinate dehydrogenases and the concentrations of lactate, ethanol and succinate (or fumarate) in the spent culture medium.

Soluble cytochromes with absorption maxima corresponding to cytochromes $c_{552}$ and $a_{1}$ were readily detected in bacteria harvested from anaerobic continuous cultures (Table 8). Furthermore, more particulate cytochrome $d$ was formed than during growth in the corresponding batch cultures, but far less cytochrome $b_{559}$ was detected in bacteria grown anaerobically with nitrate. Cytochrome $d$ was the dominant cytochrome oxidase in sulphatelimited cultures grown anaerobically with $\mathrm{NaNO}_{2}$ or aerobically, but cytochrome $o$ was the dominant oxidase in other cultures. As in the batch culture experiments, NADH oxidase of cell membranes was more active during aerobic than during anaerobic growth.

\section{DISCUSSION}

Cell yields from glucose in batch or sulphate-limited continuous cultures of $C$. freundii were only slightly higher during aerobic growth or in anaerobic cultures supplemented with nitrate or nitrite than in unsupplemented anaerobic cultures. Products typical of a mixed acid fermentation accumulated in each case. The formation of acetate instead of ethanol in cultures supplied with nitrate, nitrite or oxygen would result in substrate level phosphorylation due to the reversal of the acetate kinase reaction and would therefore explain at least part of the observed increase in cell yields. In contrast, carbon-limited continuous cultures readily adapted to a respiratory mode of metabolism when the culture was aerated and a far greater increase in cell yield resulted.

The marked variations in cytochrome complement and NADH oxidase activity between the different types of culture were entirely consistent with previously assigned functions for the various proteins: their synthesis appears to be regulated primarily by the availability of the appropriate terminal electron acceptors (Chance, 1961; Jones \& Redfearn, 1966; Cole, 1968; Haddock et al., 1976). In contrast, there was little correlation between the activities of lactate dehydrogenase and tricarboxylic acid cycle enzymes, other than succinate dehydrogenase, and their in vivo reaction velocity (as indicated by the rates of accumulation of products of glucose metabolism). The optimal conditions of $\mathrm{pH}$, substrate and coenzyme concentrations of enzymes from $C$. freundii differed from those routinely used to assay enzymes from other bacteria: appropriate modifications were therefore introduced. If the activity of an enzyme assayed under its optimal conditions accurately reflects its rate of synthesis during growth, it can be concluded that the physiology of $C$. freundii cultures was similar during aerobic or anaerobic growth when glucose was in excess and that the pattern of metabolism was essentially fermentative. The availability of oxygen or an alternative terminal electron acceptor therefore appears not to determine the rate at which tricarboxylic acid cycle enzymes are synthesized. The least active enzyme of the tricarboxylic acid cycle during aerobic growth, succinate dehydrogenase, was derepressed 12-fold in carbon-limited continuous cultures relative to sulphate-limited cultures. This suggests that catabolite repression of succinate dehydrogenase synthesis provides a major regulatory mechanism for the potential tricarboxylic acid cycle activity in this organism. Experiments described elsewhere have provided more direct evidence for these conclusions and have also demonstrated that the enzyme assays are both reproducible and closely reflect the rates of messenger RNA transcription and translation (Keevil et al., 1977a). Furthermore, since brewers' wort contains a high concentration of fermentable carbohydrate, the conclusions drawn from the batch culture experiments may also be relevant to a brewery fermentation. The increasingly widespread practice of aerating wort before and during fermentation would not prevent the formation of fermentation products, and contamination by C. freundii and its products may therefore adversely affect the quality of the beer produced. 
No attempt was made to distinguish between succinate dehydrogenase and fumarate reductase activities. We are therefore unable to state whether succinate dehydrogenase synthesis is also repressed during anaerobic growth, or whether fumarate reductase is repressed during aerobic growth. There is direct evidence for both types of regulatory mechanism in E. coli (Hirsch et al., 1963; Spencer \& Guest, 1973).

The most unexpected observation was the similarity in 2-oxoglutarate dehydrogenase activity in extracts of bacteria which had been grown aerobically or anaerobically (Tables 3 and 7). Previous studies with other species have indicated that the synthesis of this enzyme is totally repressed during anaerobic growth (Amarasingham \& Davis, 1965; Gray et al., $1966 a$; Forget \& Pichinoty, 1967; Doelle et al., 1974). Possible explanations for this apparent discrepancy are: (i) that 2-oxoglutarate dehydrogenase synthesis in $C$. freundii is catabolite-repressible and that only a basal level of activity was formed by the aerated cultures; (ii) that glutamate added to the minimal medium as a growth supplement was an inducer of enzyme synthesis even during anaerobic growth; (iii) that the gases used to generate anaerobic growth conditions contained sufficient oxygen to induce enzyme synthesis; and (iv) that this enzyme is constitutive rather than inducible. The first suggestion is unlikely to be correct because although the catabolite-repressible succinate dehydrogenase was far more active in the glucose-limited continuous culture than in the sulphate-limited culture, there was no parallel increase in 2-oxoglutarate dehydrogenase activity (Table 7). Experiments are currently in progress to determine which, if any, of the other possible explanations are correct.

This research was supported by grants from The Brewers' Society to J.S. H. and C. W. K.

\section{REFERENCES}

Amarasingham, C. R. \& Davis, B. D. (1965). Regulation of $\alpha$-ketoglutarate dehydrogenase formation in Escherichia coli. Journal of Biological Chemistry 240, 3664-3668.

Cavari, B. Z., Avi-dor, Y. \& Grossowicz, N. (1968). Induction by oxygen of respiration and phosphorylation of anaerobically grown Escherichia coli. Journal of Bacteriology 96, 751-759.

Chance, B. (1961). In Haematin Enzymes, p. 343. Edited by J. E. Falk, R. Lemberg \& R. K. Morton. Oxford: Pergamon Press.

Cole, J. E. (1968). Cytochrome $c 552$ and nitrite reduction in Escherichia coli. Biochimica et biophysica acta 162, 356-368.

Cole, J. A. \& Wimpenny, J. W. T. (1968). Metabolic pathways for nitrate reduction in Escherichia coli. Biochimica et biophysica acta 162, 39-48.

Cole, J. A. \& Rittenberg, S. C. (1971). A comparison of respiratory processes in Spirillum volutans, Spirillum itersonii and Spirillum serpens. Journal of General Microbiology 69, 375-383.

De Graaf, J. \& Stouthamer, A. H. (1971). Citrobacter freundii mutants deficient in host specificity functions and their recipient ability for foreign deoxyribonucleic acid. Journal of General Microbiology 67, 91-97.

Doelle, H.W., Hollywood, N. \& Westwood, A. W. (1974). Effect of glucose concentration on a number of enzymes involved in the aerobic and anaerobic utilisation of glucose in turbidostat cultures of Escherichia coli. Microbios 9, 221-232.

Dubowski, K. M. (1962). An aminotoluene method for body-fluid glucose determination. Clinical Chemistry 8, 215-235.
Forget, P. \& Pichinoty, F. (1967). Le cycle tricarboxylique chez Aerobacter aerogenes. Annales de l'Institut Pasteur 112, 261-290.

Fujita, T. (1966). Studies on soluble cytochromes in Enterobacteriaceae. I. Detection, purification and properties of cytochrome $c 552$ in anaerobically grown cells. Journal of Biochemistry 60, 204-215.

Gray, C. T., Wimpenny, J. W. T., Hughes, D. E. \& Mossman, M. R. (1966a). Regulation of metabolism in facultative bacteria. I. Structural and functional changes in Escherichia coli associated with shifts between the aerobic and anaerobic states. Biochimica et biophysica acta 117, 22-32.

Gray, C. T., WIMPENNY, J. W. T. \& Mossman, M. R. $(1966 b)$. Regulation of metabolism in facultative bacteria. II. Effects of aerobiosis, anaerobiosis and nutrition on the formation of Krebs cycle enzymes in Escherichia coli. Biochimica et biophysica acta 117, 33-41.

Hadpock, B. A., Downie, J. A. \& Garland, P. B. (1976). Kinetic characterisation of the membranebound cytochromes of Escherichia coli grown under a variety of conditions by using a stoppedflow dual wavelength spectrophotometer. Biochemical Journal 154, 285-294.

HAGeR, L. P. \& ITAGAKI, E. (1967). The preparation and properties of cytochrome $b_{562}$ from Escherichia coli. Methods in Enzymology 10, 373-378.

Harmon, M. A. \& Doelle, H. W. (1969). Gaschromatographic separation and determination of microquantities of the esters of the tricarboxylic acid cycle acids and related compounds. Journal of Chromatography 42, 157-169.

Hirsch, C. A., Rasminsky, M., Davis, B. D. \& 
LiN, E. C. C. (1963). A fumarate reductase in Escherichia coli distinct from succinate dehydrogenase. Journal of Biological Chemisty 238, 3770-3774.

Hough, J. S., Briggs, D. E. \& Stevens, R. (1971). Malting and Brewing Science. London: Chapman \& Hall.

Hughes, D. E. (1951). A press for disrupting bacteria and other microorganisms. British Journal of Experimental Pathology 32, 97-109.

JACQUET, M. \& KePES, A. (1969). A step sensitive to catabolite repression and its reversal by $3^{\prime}, 5^{\prime}-$ cyclic adenosine monophosphate during induced synthesis of $\beta$-galactosidase in Escherichia coli. Biochemical and Biophysical Research Communications 36, 84-92.

Jones, C. W. \& RedfeARN, E. R. (1966). Electron transport in Azotobacter vinelandii. Biochimica et biophysica acta 113, 467-481.

Keevil, C. W., Hough, J. S. \& Cole, J. A. (1977a). The effects of glucose, succinate and $3^{\prime}, 5^{\prime}$-cyclic adenosine monophosphate on the synthesis of tricarboxylic acid cycle enzymes and respiratory components in Citrobacter freundii. FEMS Microbiology Letters 1, 329-331.

Keevil, C. W., Hough, J. S. \& Cole, J. A. (1977b). Prototrophic growth of Citrobacter freundii and the biochemical basis for its apparent growth requirements in aerated media. Journal of General Microbiology 98, 273-276.

Kersters, K. \& DE LeY, J. (1966). Soluble nicotinamide adenine dinucleotide-linked primary and secondary alcohol dehydrogenases. Methods in Enzymology 9, 347-350.

KrEBS, H. A. (1937). The intermediate metabolism of carbohydrates. Lancet ii, 736-738.

LEMBERG, R. \& BARRETT, J. (1973). Cytochromes. New York: Academic Press.

Lowry, O. H., Rosebrough, N. J., Farr, A. L. \& RANDALL, R. J. (1951). Protein measurement with the Folin phenol reagent. Journal of Biological Chemistry 193, 265-275.

Magasanik, B. (1961). Catabolite repression. Cold Spring Harbor Symposia on Quantitative Biology 26, 249-256.

MASSEY, V. (1952). The crystallisation of fumarase. Biochemical Journal 51, 490-494.

Munson, T. E. (1974). Improved $\mathrm{KCN}$ medium. Applied Microbiology 27, 262-263.

Muramatsu, K. (1967). Direct colorimetric method for the determination of free ammonia in blood. Agricultural and Biological Chemistry 31, 301-308.
OCHOA, S. (1955). Isocitric dehydrogenase system (reduced nicotinamide adenine dinucleotide phosphate) from pig heart. Methods in Enzymology 1, 699-700.

Payne, W. J. (1973). Reduction of nitrogenous oxides by microorganisms. Bacteriological Reviews 37, 409-452.

Pichinoty, F. (1963). L'effet oxygéné et la biosynthèse des enzymes d'oxydoréduction bactériens. Colloques internationaux du Centre national de la recherche scientifique $24,523-526$.

RadCliffe, B. C. \& Nicholas, D. J. D. (1968). Some properties of a nitrite reductase from Pseudomonas denitrificans. Biochimica et biophysica acta 153, 545-554.

REeD, L. J. \& MuKherJeE, B. B. (1969). $\alpha-$ Ketoglutarate dehydrogenase complex from Escherichia coli. Methods in Enzymology 13, 55-61.

St John, R. T., Shah, V. K. \& Brill, W. J. (1974). Regulation of nitrogenase synthesis by oxygen in Klebsiella pneumoniae. Journal of Bacteriology 119 , 266-269.

SMITH, L. (1955). Cytochromes $a, a_{1}, d$ and $a_{3}$. Methods in Enzymology 2, 732-740.

SPENCER, M. E. \& Guest, J. R. (1973). Isolation and properties of fumarate reductase mutants of Escherichia coli. Journal of Bacteriology 114, 563-570.

SzeKely, E. (1967). Spectrophotometric determination of nitrate with $p$-diaminodiphenylsulphone and diphenylamine-p-diaminodiphenylsulphone. Talanta 14, 941-950.

TABer, H. W. \& Morrison, M. (1964). Electron transport in staphylococci. Properties of a particle preparation from exponential phase Staphylococcus aureus. Archives of Biochemistry and Biophysics 105, 367-379.

Tyler, B., Loomis, W. F. \& MagasaniK, B. (1967). Transient repression of the lac operon. Journal of Bacteriology 94, 2001-2011.

Weiner, J. P., RalPh, D. J. \& TAYlor, L. (1975). Nitrate and nitrite in brewery fermentations. Proceedings of XV International Brewery Conference, Nice, 565-579.

Weitzman, P. D. J. (1969). Citrate synthase from Escherichia coli. Methods in Enzymology 13, 22-23.

Yамамото, I. \& Isнiмото, M. (1975). Effect of nitrate reduction on the enzyme levels in carbon metabolism in Escherichia coli. Journal of Biochemistry 78, 307-315. 